\title{
Working with Linguistically Diverse Classes across the Disciplines: Faculty Beliefs
}

\begin{abstract}
Jennifer E. Haan ${ }^{1}$, Colleen E. Gallagher ${ }^{2}$ and Lisa Varandani ${ }^{3}$
Abstract: The rapid growth of international students at United States universities in recent years (Institute of International Education, 2013) has prompted discussions about how best to serve this population in and out of the classroom. This article reports on faculty cognitions (Borg, 2006) regarding internationalization and the teaching of international students who are emergent multilinguals. Researchers surveyed faculty members on one campus about their beliefs regarding internationalization, techniques for instruction in culturally and linguistically diverse classrooms, and their own efficacy in teaching international students. Results indicate a theory-reality split in beliefs about internationalization and techniques for teaching international students along with relatively low levels of self-efficacy in working with emergent multilinguals. The article discusses implications for faculty-administration collaboration and faculty development in linguistically-responsive instruction.
\end{abstract}

Keywords: international students, university internationalization, linguistically-responsive instruction, teaching multilingual students

\section{Introduction}

Recently, universities have developed and implemented internationalization strategies involving various aspects of the institution, including strategic plan development, international programming, and international student recruitment (Maringe, 2011). This growth in international student recruitment has resulted in an increase in international students at universities in Englishspeaking countries (see table 1) ranging from $42 \%$ - 52\% over the last five years (Institute of International Education, 2013).

Table 1. Numbers of international students in English-speaking countries ${ }^{1}$

\begin{tabular}{|l|l|l|}
\hline International students, 2013 & International students, 2005 & \\
\hline 488,380 & 344,335 & United Kingdom \\
\hline 242,351 & 160,000 & Australia \\
\hline 819,644 & 564,766 & United States \\
\hline
\end{tabular}

${ }^{1}$ From Institute of International Education (2013)

\footnotetext{
${ }^{1}$ Department of English, University of Dayton, 300 College Park, Dayton, OH, 45469, jhaan1@udayton.edu

${ }^{2}$ Department of Teacher Education, University of Dayton, 300 College Park, Dayton, OH, 45469, cgallagher1@udayton.edu

${ }^{3}$ Department of Curriculum and Instruction, New Mexico State University, 1780 E. University Ave., Las Cruces,

NM 88003, lisa.varandani@gmail.com
} 
As global demand for higher education grows and internationalization efforts expand, these numbers will likely continue to rise.

Although the implementation of internationalization practices varies widely across different campuses, in general, administrators are considering the benefits of internationalizing the campus, curriculum, and student body. Universities cite several benefits that compel internationalization, including perceived global standing (Foskett, 2010; Taylor, 2010), institutional effectiveness (Douglass, 2010), opportunities to foster global citizenship (Barker et al., 2013; Clifford \& Montgomery, 2011) and the enhanced tolerance, respect, and understanding important in multicultural settings (Bevis \& Lucas, 2007; Killick, 2013).

In many ways, this emphasis on the internationalized campus and the accompanying growth in student mobility is changing higher education. Just as open admission policies in the 1960s changed the student body and approaches to curriculum and instruction (Rose, 1985), so today internationalization efforts have implications for every aspect of the institution. This type of internationalization can be described as transformative in that it doesn't simply measure the numbers of students or programs, but changes the character of the institution and the way the students, administration, and the institution as a whole view themselves. Schoorman (2000) describes this type of transformative internationalization as "an ongoing, counterhegemonic education process that ... entails a comprehensive, multifaceted program of action that is integrated into all aspects of education” (p. 5).

Although there is clear potential for benefits as a result of increased internationalization, these benefits are sometimes unrealized because of the challenges for students and faculty adjusting to a changing institutional environment. One such challenge is language learning for international students who are emergent multilinguals. These multilinguals have the task of acquiring not only the disciplinary knowledge and academic language related to their chosen areas of study, but also of concurrently developing their English proficiency to high levels for use in social, professional and academic settings. Furthermore, international students are often treated as cultural or linguistic Others as they pursue their studies abroad, leading to feelings of loneliness and isolation (Marginson, 2013). Faculty, too, are challenged as they teach classes with students whose cultural and linguistic backgrounds may be unfamiliar to them, classes which are reflective of the growing cultural, linguistic, and educational diversity of the student body. In this context, faculty are asked to create learning environments that meet the needs of both international and domestic students, yet little is known about faculty’s ability to adjust to these changes.

\section{Research on Faculty and Internationalization}

While limited prior work has focused on faculty beliefs regarding international students, researchers in international education, second language (L2) writing, and L2 teaching have focused on internationalization efforts and their relationship to students, faculty, and curriculum. Studies from Australia and the United Kingdom have used interviews and surveys to examine the relationship between international students and faculty (Ryan, 2005; Ryan \& Viete, 2007; Sovic, 2013). These studies indicate that students feel inhibited by a lack of voice in their classes, leading to isolation as they adjust to the university classroom. Ryan and Viete (2009) use the results of their studies to point out that faculty often approach international students from a deficit perspective (Sawir, 2005; Archer, 2007), which blames the students and their language skills for difficulty in the classroom without considering wider classroom, institutional, and cultural factors.

Journal of the Scholarship of Teaching and Learning, Vol. 17, No. 1, February 2017. josotl.indiana.edu 
Although such studies have examined international students' perspectives on faculty response to internationalization, far fewer have looked specifically at faculty perspectives. In addressing internationalization in higher education, Andrade (2010) conducted a survey of 93 instructors at a US university. The survey addressed the faculty's perception of international student language skills, the effect of multilingual students on the class, approaches to working with multilingual students, and institutional responses to multilinguals. The researcher views the findings as "positive in that faculty appear sensitive to L2 students' learning needs and adjust their teaching methods at least some of the time to accommodate them" (p. 230). But she also notes that faculty had "minimal interest in focusing on improving students' English skills or learning more about pedagogical methods for teaching NNESs” (p. 230).

More narrowly, L2 writing scholars have examined faculty response to increasing numbers of L2 writers in their classrooms (Zamel \& Spack, 2004; Janopoulos, 1992; You \& You, 2013; Kam \&Meinema, 1995). Zamel and Spack (2004) present narratives from faculty members describing successful approaches to integrating multilingual writers in their classes. You and You (2013) also report that when moving from an American university to an English-medium Chinese university context faculty across various disciplines adjusted their assignments based on student need, institutional constraints, and cultural contexts. These L2 writing studies shed light on the experiences of faculty members as they work with multilinguals, but because they are limited in both scope and number, additional research is needed to better understand faculty beliefs and practices across the disciplines.

\section{Research on Language Teacher Cognition}

Research in language teacher cognition lays the foundation for further work with faculty instructors of multilinguals across the disciplines. Defined as "the network of beliefs, knowledge, and thoughts which L2 teachers hold about all of the aspects of their profession and draw on in their work” (Sanchez \& Borg, 2014, p. 45), teacher cognition is influenced by instructors' own schooling experiences, professional coursework, and professional experiences. One specific area of cognition research examines instructors' beliefs about their own preparedness for demands in teaching, or self-efficacy. Self-efficacy, or “people's beliefs about their capabilities to exercise control over their own level of functioning and other events that affect their lives" (Bandura, 1993, p. 118), impacts behavior, including teaching behavior. Other cognitive influences that can affect classroom practices include principles that guide decisions, affective involvement, background knowledge, classroom management concerns, individual learner attributes, and aspects of pedagogical knowledge (Borg, 2006).

Because of this complex link between cognitions and classroom practice, an important part of understanding faculty response to internationalization is knowing what instructors believe about international students, instructional practices for emergent multilinguals, and their own ability to work with multilinguals. Currently, this body of work primarily focuses on student perspectives and specific areas such as L2 writing. Given the changing demographics of higher education, an understanding of faculty beliefs is important in promoting quality teaching for all students.

This study seeks to address that need by addressing the following research questions:

1. What are faculty beliefs about internationalization on campus?

2. What are faculty beliefs about instructional practices for working with multilinguals?

3. What are faculty beliefs about their own self-efficacy in teaching multilinguals?

Journal of the Scholarship of Teaching and Learning, Vol. 17, No. 1, February 2017. josotl.indiana.edu 


\section{Methods}

The investigators used an online survey to address these questions. Surveys are a common approach to gathering data in language teacher cognition research and the self-reported nature of the data can make them a good way to find out about instructors' ideals and beliefs (Borg, 2006). The anonymity of the survey should have encouraged honest reporting of beliefs and decreased respondents' tendency to report what they think investigators want to hear (Borg, 2006).

\section{Context}

This study was conducted at a mid-size, private, comprehensive university in the U.S. The student body of about 10,000 graduate and undergraduate students was comprised of approximately 16\% international students as of the fall 2013 semester. As with many institutions of higher education, this university has experienced a dramatic recent increase in international student enrollment. In fact, over the last 5 years, the university has experienced a 394\% growth in the number of international students. Some are directly admitted with sufficient English language proficiency test scores while others matriculate from the university’s intensive English program.

\section{Data Collection and Analysis}

This research group followed best practices (Cox, 1996) to develop a survey of faculty beliefs and practices for working with international students. The survey consisted of 12 Likert-type questions with optional open-ended comments, and addressed internationalization, classroom practices, and faculty support. The research team drafted the survey using language that would be clear to nonspecialists in second language teaching, piloted the questions with instructors who were part of the targeted population of respondents, and made final revisions based on feedback and responses.

The survey was administered to over 500 full-time and adjunct faculty members online over a period of three weeks in May 2013. In total, the response rate was 39\%. The respondents included faculty from each unit with undergraduate students across the university, as indicated in table 2 .

Table 2: Number of respondents by unit

\begin{tabular}{|l|l|}
\hline Number of Respondents & Unit \\
\hline 23 & Engineering \\
\hline 20 & Education and Health Sciences \\
\hline 25 & Business Administration \\
\hline 17 & Math and Science \\
\hline 13 & Social Science \\
\hline 44 & Humanities \\
\hline
\end{tabular}

Journal of the Scholarship of Teaching and Learning, Vol. 17, No. 1, February 2017. josotl.indiana.edu 


\begin{tabular}{|l|l|}
\hline 12 & Arts \\
\hline 3 & Other \\
\hline 35 & None given \\
\hline 192 & Total \\
\hline
\end{tabular}

Respondents teach students from across all levels of study offered at the university, with most teaching both graduates and undergraduates. Although respondents varied in the amount of experience teaching international students, they commonly reported teaching 10-20 international students per semester, though many noted that the number varies greatly by class and semester.

Responses to Likert-type questions were aggregated for all respondents and average responses for each answer choice were calculated and reported in percentages. The written comments were grouped according to the survey question that had prompted them and coded for emergent themes relevant to the research questions on internationalization, instruction, and selfefficacy.

\section{Results}

\section{Faculty Beliefs about Internationalization on Campus}

The first research question addressed faculty attitudes about internationalization. Two questions from the survey addressed this topic: (a) Our campus community benefits from having a growing international student population and (b) The university provides sufficient support structures for international students. Together, data from these questions provide an interesting and somewhat contradictory picture of a faculty grappling with a marked increase in the international student population.

Overall, faculty displayed a positive attitude toward the idea of internationalization, with $65 \%$ of respondents agreeing or strongly agreeing that the campus community benefits from the growing international student population and another $22 \%$ remaining neutral. In contrast, the faculty provided a negative response regarding the level of support the university was providing; only $12 \%$ agreed or strongly agreed that the university was doing enough. Table 3 provides greater detail.

Table 3. Percentage of faculty indicating various beliefs about internationalization on campus

\begin{tabular}{|l|l|l|l|l|l|}
\hline $\begin{array}{l}\text { Strongly } \\
\text { disagree }\end{array}$ & Disagree & Neutral & Agree & $\begin{array}{l}\text { Strongly } \\
\text { agree }\end{array}$ & Statement \\
\hline $5 \%$ & $8 \%$ & $22 \%$ & $34 \%$ & $30 \%$ & $\begin{array}{l}\text { Our campus community } \\
\text { benefits from having a } \\
\text { growing international } \\
\text { student population. } \\
(\mathrm{n}=194)\end{array}$ \\
\hline
\end{tabular}

Journal of the Scholarship of Teaching and Learning, Vol. 17, No. 1, February 2017. josotl.indiana.edu 


\begin{tabular}{|l|l|l|l|l|l|}
\hline $34 \%$ & $25 \%$ & $29 \%$ & $3 \%$ & $\begin{array}{l}\text { The university provides } \\
\text { sufficient support } \\
\text { structures for } \\
\text { international students. } \\
(\mathrm{n}=194)\end{array}$ \\
\hline
\end{tabular}

Respondents provided more insight in written comments. Comments such as the following emphasized the benefits of internationalization:

(1) Exposure to other cultures is extremely beneficial to our traditional and very homogeneous ... population.

Thus for a campus perceived by this respondent as lacking in diversity, international students add variety to the campus community.

On the other hand, many respondents provided comments that contradict the overall positive evaluation of internationalization in the Likert-type question. They tended to view internationalization positively in theory, but had concerns with the way it was being carried out on campus. The following quote is illustrative of this theory-reality disjunction:

(2) I agree that a global learning environment offers students a wonderful chance to grow and learn from others-however- I have three major concerns...

Some faculty members wrote explanations for their reservations that connected explicitly with their perceptions of the university's role in internationalization. Respondents, on the whole, questioned the university's motivation for admitting international students and felt that the university needed to set more stringent international admission standards. An illustrative example follows:

(3) While a growing international population may theoretically have the potential to benefit our community, the way it is being implemented...works against us recognizing any benefit. 1. Students are being brought to campus who lack the basic skills to be successful, and there is not sufficient infrastructure to support them. The negative consequences affect these students, the faculty, and the other ... students. Simply expecting the instructors to change courses (or to apply different evaluation standards) to accommodate the abilities of international students is not a solution. 2. Importing a large population of students from China does not really provide "diversity," it simply provides more students. I'm not sure how this is a benefit.

This comment explicitly addresses a central finding of this study: while faculty indicated positive feelings toward the idea of internationalization, they indicated more nuanced and mixed perceptions of the reality of internationalization in progress on campus. This respondent and others questioned the value of international students in contributing to diversity on campus. Furthermore, as the quantitative data shows and this respondent alludes to, many faculty members felt that the university did not have adequate support systems in place for international students. The next written responses are representative with respect to student support:

(4) We need much better support for the international students. These are intelligent people. But all too often, they require additional language and cultural support in order to make the most of their experiences here.

(5) I feel the support structures that are being put in place are moving in the right direction, but more needs to be done.

Journal of the Scholarship of Teaching and Learning, Vol. 17, No. 1, February 2017. josotl.indiana.edu 
This belief that the responsibility for supporting emergent multilinguals lies largely with the university outside of the classroom is addressed more fully in the next section.

Faculty Beliefs about Instructional Techniques for Emergent Multilinguals

In addition to questions relating to general perceptions of internationalization, the survey asked faculty to indicate whether or not they believed the instructional techniques for international students benefit all students. While this question elicited a wide range of responses from faculty, overall they tended to be negative, with only 33\% of respondents replying with agree or strongly agree and 36\% of respondents selecting disagree or strongly disagree. Interestingly for faculty development issues, $32 \%$ were neutral, indicating perhaps a segment of the population open to discussion on the topic.

Table 4: Percentage of faculty indicating various beliefs about instructional practices for NNS

\begin{tabular}{|l|l|l|l|l|l|}
\hline $\begin{array}{l}\text { Strongly } \\
\text { disagree }\end{array}$ & Disagree & Neutral & Agree & $\begin{array}{l}\text { Strongly } \\
\text { agree }\end{array}$ & Statement \\
\hline $9 \%$ & $27 \%$ & $32 \%$ & $21 \%$ & $11 \%$ & $\begin{array}{l}\text { Using instructional } \\
\text { techniques for } \\
\text { international students } \\
\text { benefits all students. } \\
(\mathrm{n}=194)\end{array}$ \\
\hline
\end{tabular}

The written comments this statement generated, however, were useful in better understanding this negative perception. In their responses to this question, some faculty indicated they simply didn't understand what was meant by instructional techniques for international students. A number of respondents stated "I don't know what this means." Others asked "Can you explain what techniques you are asking about?" The very fact that some respondents did not know how to interpret this question suggests that perhaps some are not familiar with the idea of adapting instruction to meet students' linguistic needs. In and of themselves, these responses indicate an area for potential faculty development efforts.

Many additional respondents, however, equated instructional techniques for international students with lowering their curricular or instructional standards, as evidenced by the following quote:

(6) Spending class time on remedial skills for those who need help with language tends to cheat the students who possess college level skills. At the University level, it is wrong to dumb down content to pitch to the lowest skill levels. The work I do compensating for skill deficiencies is performed during office hours.

Others didn't specifically equate adjusting their instructional techniques with lowering curricular standards, but were nonetheless resistant to incorporating new techniques in their courses. These instructors, in particular, seemed to be struggling with questions about their role and responsibility in international student instruction. Here, many respondents reiterated that the responsibility for supporting international students lies outside of their classrooms, either in increased university support structures or in stricter admissions requirements.

Journal of the Scholarship of Teaching and Learning, Vol. 17, No. 1, February 2017. josotl.indiana.edu 
(7) My opinion is their language skills need to be brought up to the level that they can be successful in our courses without our having to make major adjustments to our teaching.

(8) The support structures for international students need to be further developed. Faculty can (and do) take time to assist international students (like all students) on subject matter. Not all faculty can or should become ESL experts.

(9) Yes, of course there are things that faculty can learn about working with international students. But the majority of support for these students needs to happen outside the classroom.

This feeling that the primary supports for international students should be outside of the classroom can lead to tension between faculty and administration. On the one hand, the university benefits from international student presence on campus, both financially and in terms of international reputation. On the other hand, the rapidly shifting student population can lead to pedagogical challenges for faculty. One respondent encapsulated this tension, stating:

(10) While benefiting tremendously economically from increasing international students, the university has done little in the way of assuring that the structures are in place for them to succeed. As the response has rolled out in the past couple of years, it seems that the burden for handling this will be shifted to the faculty who will now be forced to undergo numerous trainings, alter their course materials and teaching styles, and the like. In other words, the university's budget increases while faculty - who are not going to see a pay increase for the additional work associated with the internationalization of the university bear the burden.

Here we can see the tension between the faculty and the administration related to the responsibility for international student instruction. The faculty perception is that the university is receiving all of the benefits without paying any of the costs. This leads some to view the necessity of responding to the needs of the changing student population as a burden.

\section{Faculty Self-Efficacy in Teaching Emergent Multilinguals}

As discussed earlier, teacher self-efficacy is linked with teacher practices (Bandura, 1993) and so understanding faculty self-efficacy in working with multilinguals is important for providing faculty development in this area. To better understand instructor self-efficacy, the survey asked faculty to respond to questions about their own comfort level in teaching and communicating with international students, encouraging class participation, responding to written work, and engaging in cultural discussions. Respondents were also encouraged to provide comments and explanations.

Faculty self-efficacy varied depending on the area of focus. As Table 5 shows, the area in which faculty displayed most confidence was discussing cultural issues, with $77 \%$ of respondents indicating comfort in this area. With other issues of classroom communication and response, however, faculty seemed less comfortable. For communication skills, multilingual student participation, and grading multilingual writers' work, over half of the participants were neutral or negative in evaluating their own abilities, suggesting lower overall self-efficacy in these areas. Additionally, over half of respondents were neutral or negative in evaluating their overall skills for teaching international students, suggesting lower collective self-efficacy in this area as well.

Journal of the Scholarship of Teaching and Learning, Vol. 17, No. 1, February 2017. josotl.indiana.edu 
Table 5: Percentage of faculty indicating various degrees of self-efficacy in strategies for teaching emergent multilinguals

\begin{tabular}{|l|l|l|l|l|l|l|}
\hline N/A & $\begin{array}{l}\text { Strongly } \\
\text { disagree }\end{array}$ & Disagree & Neutral & Agree & $\begin{array}{l}\text { Strongly } \\
\text { agree }\end{array}$ & Statement \\
\hline $0 \%$ & $6 \%$ & $28 \%$ & $22 \%$ & $32 \%$ & $12 \%$ & $\begin{array}{l}\text { I feel I have the skills I need to } \\
\text { successfully teach international } \\
\text { students. (n=193) }\end{array}$ \\
\hline $2 \%$ & $4 \%$ & $21 \%$ & $28 \%$ & $36 \%$ & $9 \%$ & $\begin{array}{l}\text { I am able to communicate } \\
\text { effectively with the international } \\
\text { students in my classes. (n=185) }\end{array}$ \\
\hline $3 \%$ & $10 \%$ & $27 \%$ & $24 \%$ & $28 \%$ & $8 \%$ & $\begin{array}{l}\text { I am able to get international } \\
\text { students to participate in my } \\
\text { classes. (n=186) }\end{array}$ \\
\hline $4 \%$ & $13 \%$ & $21 \%$ & $17 \%$ & $35 \%$ & $9 \%$ & $\begin{array}{l}\text { I feel comfortable grading } \\
\text { international students' written } \\
\text { work. (n=186) }\end{array}$ \\
\hline $5 \%$ & $3 \%$ & $4 \%$ & $12 \%$ & $42 \%$ & $35 \%$ & $\begin{array}{l}\text { I feel comfortable discussing } \\
\text { cultural issues with students from } \\
\text { a variety of cultural backgrounds. } \\
\text { (n=185) }\end{array}$ \\
\hline
\end{tabular}

When reading the qualitative data related to this question, however, a more complete picture appears. Comments regarding faculty preparedness tended to fall into two categories: one indicating interest in developing instructional techniques for multilinguals but expressing limitations in time or background knowledge, and the other expressing the belief that adjustments to instruction should not be necessary. The following quotes represent the former view:

(11) I am learning. I have had 4 international students over the past 2-3 years. Each is very different and English skills have been particularly weak in 2 of the four students. My noninternational students expressed concern this term regarding the time it was taking each of us to work one-on-one with our international students.

(12) My skills in teaching international students are limited to my discipline. I don't feel capable of teaching them better English (oral comm or grammar). But I can help them better understand concepts in my field.

Many comments in response to these questions, however, represented the latter view, that although instructors do not always feel comfortable working with international students, this is due not to their own lack of preparedness, but rather to the students' poor English.

(13) The professional development activities I had noticed seemed focused on how our courses had to change substantially to accommodate International students. My opinion is their language skills need to be brought up to the level that they can be successful in our courses without our having to make major adjustments to our teaching.

Journal of the Scholarship of Teaching and Learning, Vol. 17, No. 1, February 2017. 
(14) I feel I have the skills, but the language barrier often leaves me not knowing if a student is understanding my class or not.

Thus from the viewpoint of some respondents, successful international student outcomes are more a factor of individual student language proficiency and less of an instructor's pedagogical skills.

Nonetheless, according to another question, $70 \%$ of respondents indicated that professional development opportunities would be helpful. Here again is indication of a complicated set of beliefs regarding aspects of internationalization. While on the one hand, faculty tend to acknowledge their limitations in skills for teaching emergent multilinguals and the benefit of professional development opportunities, many also resisted the idea of changing instruction for this group.

In sum, increasing internationalization has the potential to transform universities into rich environments for intercultural learning and interaction, but this type of transformation can only occur when students, faculty, and administration work together on the ongoing internationalization project. This study has several key findings. First, beliefs about internationalization on campus were mixed: respondents were fairly positive toward the idea of internationalization and more negative about the reality as it impacted their work. Second, respondents held misunderstandings about instructional techniques for international students, and third, respondents indicated low selfefficacy in their ability to serve international students effectively. This research highlights the complexities of working in a newly internationalized institutional context and brings up issues for faculty and administration to consider in the development and implementation of internationalization programs and policies. In particular, the research has important implications in the areas of faculty-administration cooperation and in faculty development in linguisticallyresponsive instruction.

\section{Discussion and Implications}

\section{Beliefs about Internationalization on Campus}

The results have important implications for an understanding of faculty response to internationalization from both theoretical and practical perspectives. First, when viewed in light of research on faculty cognition, the results clearly indicate a split between valuing an internationalized student body in theory and doing so in practice when faced with the challenge of teaching culturally and linguistically diverse classes. This mismatch echoes Borg's (2006) observation that teacher cognitions, teaching context, and teaching practice interact in complex ways; and that context often serves as a mediating force which produces incongruence between beliefs and practices. Indeed, the context of a quickly growing international population on this study's campus has exposed an inconsistency in beliefs themselves, with faculty both approving of internationalization and expressing reservations about their own roles in working with a changing student population. It also parallels De Vos's (2003) statement regarding conflicting attitudes toward international students: "For many, international students are simultaneously a source of contempt (for their inadequate English language skills), resentment (that we have to accept them at all) and paradoxically, anxiety ("will they like us [and tell their friends to come and study here so that I still have a job”])?” (p. 163).

The results also point to a need for increased communication between the administration and the faculty about the role of internationalization in the institution's mission. Survey responses indicated a lack of clarity about the responsibility for international student support. Should it be 
provided by structures outside of the classroom or by the faculty in the form of curricular transformation and adaptation? If the goal of internationalization includes transformative learning, this cannot be an either-or question; there must be both engagement from the faculty and support from the administration. Without both, international students will continue to be considered marginalized Others who require consistent mediation, rather than as whole beings who bring a diverse array of ideas, viewpoints, challenges, and questions. To build a campus where international students are viewed as integral parts of the educational experience, rather than as guests or burdens, the faculty and administration must work together to develop policies and opportunities for support for everyone involved.

This may involve campus-wide discussions of entrance requirements, particularly as they relate to English language and other admission standards. It also involves support for students outside the classroom in the form of orientation, tutoring and adjustment programs. And finally, it involves varied support for faculty engaged in the curricular transformation required by internationalization. Merrick (2013) notes that faculty participation in internationalization initiatives is often not incentivized, and that "Research performance, rather than teaching excellence or administrative competence continues to be the overriding criterion for promotion" in many universities. This emphasis provides little motivation for faculty to do the work that internationalization requires, "thus, although the system may prioritize the recruitment of international students, it fails to reward those who work to ensure that those students' experiences are positive" (p. 35). Institutions of higher education interested in developing internationalized campuses could work to provide the time, space and incentives that recognize faculty work in this area.

\section{Beliefs about Instructional Practices and Faculty Self-Efficacy}

Faculty's beliefs about instructional practices were also complex, indicating both a resistance to the idea that teaching practices should change and an interest in professional development in light of their sense of self-efficacy in the classroom. First, while many respondents reported using instructional strategies that could be helpful for multilinguals and all learners, many resisted the survey's implied suggestion that faculty change their instruction to meet the needs of multilingual learners. Some even explicitly stated that they should not be expected to become what one called "ESL experts." This inevitably raises the question of the role of language in teaching across the disciplines.

To address this issue, it may be helpful to consider that to a certain extent, all faculty are instructors of language in their disciplines. As Gee (1996) points out, part of mastering an academic discipline requires reading, writing, thinking, understanding and speaking like a member of that academic community, so inevitably a faculty member is concerned not only with disciplinary content but also with advanced literacy in the discipline, a concern evident in common instructional foci such as vocabulary, discipline-specific writing assignments, and oral presentations. Indeed, language is the vehicle for communicating information; helping students organize new information; and assessing whether students recall, comprehend and apply that information successfully. Language, then, is a central tool in teaching and learning (Halliday, 1993) and as such, even when unexamined or unacknowledged, all faculty become, to some extent, de facto language instructors. All students can benefit from support in acquiring the vocabulary, argumentation styles and writing conventions of their disciplines.

Journal of the Scholarship of Teaching and Learning, Vol. 17, No. 1, February 2017. josotl.indiana.edu 
Many techniques for supporting academic language development for all students are also useful in supporting emergent multilinguals. Thus, although it may be impractical for all faculty to become L2 experts, a working knowledge of instructional techniques beneficial for multilinguals can be helpful for teaching increasingly linguistically diverse classes. As student populations change, instructional practices must change as well to continue to meet the students' needs. Moreover, just as student needs vary by group, individual needs vary as well. Using linguistically-responsive and supportive practices and responding flexibly to students' varying needs promotes equitable educational outcomes for all students. This implies a variety of methods for communicating information; helping students process, comprehend and store that information; and having them demonstrate an understanding of that information.

Providing professional development opportunities that inform faculty of strategies for linguistically-responsive instruction could help bolster the instructional self-efficacy of faculty members while simultaneously improving educational processes and outcomes. Professional development in implementing linguistically-responsive instruction should provide faculty with pedagogical strategies that take into account students' language proficiency, principles of second language acquisition, and the language demands of the class (Coady, Harper \& DeJong, 2011; Author, 2014; Lucas, Villegas, \& Freedson-Gonzalez, 2008). Such faculty development must also take into account the specific culture and context of the higher education workplace and the needs of instructors and students so that it is practical, accessible and useful.

This study, of course, has limitations. It is a study of faculty cognition at a single university, looking only at self-reported beliefs. Additional work across institutions and with a greater number of instructors would be beneficial. Moreover, a first-hand look at instructional practices through methods such as observation and ethnography would provide a more complete and accurate picture about classroom practices. Although it is narrow in scope, the study nonetheless paints a portrait of the challenges and opportunities in teaching linguistically diverse classes across the disciplines. If we are committed to developing internationalized and inclusive institutions, an understanding of faculty beliefs and practices is an important starting point. With increased dialogue among all university constituents, effective faculty development in linguistically-responsive instruction, and further research about faculty beliefs and practices, institutions of higher education can develop truly international learning environments that are supportive and effective for all students.

Journal of the Scholarship of Teaching and Learning, Vol. 17, No. 1, February 2017. josotl.indiana.edu 


\section{References}

Archer, L. (2007). Diversity, equality and higher education: A critical reflection on the ab/uses of equity discourse within widening participation. Teaching in Higher Education, 12, (5/6), 635-653. doi: 10.1080/13562510701595325

Andrade, M. S. (2010). Increasing accountability: Faculty perspectives on the English language competence of nonnative English speakers. Journal of Studies in International Education, 14 (3), 221-239. doi: 10.1177/1028315308331295

Barker, M. C., Hibbins, R. T., \& Woods, P (2013). Bringing forth the graduate as a global Citizen. In S. Sovic \& M. Blythman (Eds.), International students negotiating higher education (pp. 142-154). London: Routledge.

Baker, A. (2014). Exploring teachers' knowledge of second language pronunciation techniques: Teacher cognitions, observed classroom practices, and student perceptions. TESOL Quarterly, 48 (1), 136-163.

Bandura, A. (1993). Perceived self-efficacy in cognitive development and functioning. Educational Psychologist, 28 (2), 117-148.

Bevis, T. B., \& Lucas C. J. (2007). International students in American colleges and universities. New York: Palgrave Macmillan.

Birello, M. (2012). Teacher cognition and language teacher education: Beliefs and practice. A conversation with Simon Borg. Bellaterra Journal of Teaching \& Learning Language \& Literature, 5 (2), 88-94.

Borg, S. (2006). Teacher cognition and language education: Research and practice. New York, NY: Continuum.

Clifford, V., \& Montgomery, C. (2011). Internationalisation of the curriculum for global citizenship in higher education. In V. Clifford, \& C. Montgomery (Eds.), Moving towards internationalisation of the curriculum for global citizenship in higher education (pp. 1321), Oxford, UK: Oxford Brookes University.

Coady, M., Harper, C. A., \& De Jong, E. J. (2011). From preservice to practice: Mainstream elementary teacher beliefs of preparation and efficacy with English language learners in the state of Florida. Bilingual Research Journal 34, (2), 223-239.

Cox, J. (1996). Your opinion please! How to build the best questionnaires in the field of education. Thousand Oaks, CA: Corwin Press.

De Jong, E. J., \& Harper, C. A. (2005). Preparing mainstream teachers for English-language learners: Is being a good teacher good enough? Teacher Education Quarterly, 32 (2), 101-124.

Journal of the Scholarship of Teaching and Learning, Vol. 17, No. 1, February 2017. josotl.indiana.edu 
Devos, A. (2003). Academic standards, internationalization, and the discursive construction of "the international student." Higher Education Research and Development, 22 (3), 155166.

Douglas, D. (2000). Assessing language for specific purposes. Cambridge: Cambridge University Press.

Foskett, N. (2010). Global markets, national challenges, local strategies: The strategic challenge of internationalization. In F. Maringe \& N. Foskett (Eds.), Globalization and internationalization in higher education (pp. 101-124). London: Continuum.

Author (2014). Supporting emergent bilinguals through linguistically appropriate instruction. In G. Onchwari \& J. Keengwe (Eds.), Cross-cultural considerations in the education of young immigrant learners (pp. 85-102). Hershey, PA: IGI Global.

Gee, James P. (1996). Social linguistics and literacies. Bristol, UK: Taylor and Francis.

Halliday, M. A. K. (1993). Towards a language-based theory of learning. Linguistics and Education, 5, (2), 93-116.

Institute of International Education. (2013). Open doors data: International Students: Enrollment trend, 1948-2014. Retrieved from http://www.iie.org/opendoors

Janopoulos, M. (1992). University faculty tolerance of NS and NNS writing errors: A comparison. Journal of Second Language Writing,1 (2), 109-121.

Kam, A. \& Meinema, Y. (2005). Teaching academic writing to international students in an interdisciplinary writing context: A pedagogical rough guide. Across the Disciplines, 2.

Killick, D. (2013). Global citizenship and campus community. In J. Ryan (Ed.), Cross-cultural teaching and learning for home and international students: internationalization of pedagogy and curriculum in higher education (pp. 182-195), London: Routledge.

Lucas, T., Villegas, A., \& Freedson-Gonzalez, M. (2008). Linguistically responsive teacher education: Preparing classroom teachers to teach English language learners. Journal of Teacher Education, 59 (4), 361-373. doi: 10.1177/0022487108322110

Marginson, S. (2013). Equals or others? Mobile students in a national bordered world. In S. Sovic \& M. Blythman (Eds.), International students negotiating higher education (pp. 927). London: Routledge.

Maringe, F. (2011). Higher education transitions: From international to global institutions. In V. Clifford \& C. Montgomery, Moving Towards Internationalisation of the Curriculum for Global Citizenship in Higher Education (pp. 27-46). Oxford: Oxford Brookes University.

Merrick, B. (2013). Whose initiative? International student policy in the UK. In S. Sovic \& M. Journal of the Scholarship of Teaching and Learning, Vol. 17, No. 1, February 2017. josotl.indiana.edu 
Blythman (Eds.), International students negotiating higher education (pp. 28-38). London: Routledge.

Rose, M. (1985). The language of exclusion: Writing instruction at the university. College English, 47 (4), 341-359.

Ryan, J. (2005). Improving teaching and learning practices for international students: Implications for curriculum, policy, and assessment. In J. Ryan \& J. Carroll (Eds.), Teaching international students: Improving learning for all (pp. 92-100). London, Routledge.

Ryan, J., \& Viete, R. (2009). Respectful interactions: Learning with international students in the English-speaking academy. Teaching in Higher Education, 14 (3), 303-314.

Sanchez, S. H., \& Borg, S. (2014). Insights into L2 teachers’ pedagogical content knowledge: A cognitive perspective on their grammar explanations. System 44, 45-53.

Sawir, E. (2005). Language difficulties of international students in Australia: The effects of prior learning experience. International Education Journal, 6 (5), 567-580.

Schoorman, D. (2000). What really do we mean by ‘internationalization’? Contemporary Education, 71 (4), 5-11.

Sovic, S. (2013). Classroom encounters: International students' perceptions of tutors in the creative arts. In S. Sovic \& M. Blythman (Eds.), International students negotiating higher education (pp. 87-103). London: Routledge.

Taylor, J. (2010). The management of internationalization in higher education. In F. Maringe \& N. Foskett (Eds.), Globalization and internationalisation in higher education: Theoretical, strategic and management perspectives (pp. 97-107). London: Continuum International Publishing Group.

You, Xiaoye \& You, Xiaoqiong. (2013). American content teachers' literacy brokerage in multilingual university classrooms. Journal of Second Language Writing, 22, 260-276. doi.org/10.1016/j.jslw.2013.02.004

Zamel, V. (2004). Strangers in academia: The experiences of faculty and ESOL students across the curriculum. In V. Zamel \& R. Spack (Eds.), Crossing the curriculum: Multilingual learners in college classrooms (pp. 3-17), Mahwah, NJ: Lawrence Earlbaum Associates.

Journal of the Scholarship of Teaching and Learning, Vol. 17, No. 1, February 2017. josotl.indiana.edu 